Dhaka Univ. J. Biol. Sci. 23(2): 101-107, 2014 (July)

\title{
AN EFFICIENT DNA EXTRACTION METHOD FROM BONE AND TOOTH SAMPLES BY COMPLETE DEMINERALIZATION FOLLOWED BY THE USE OF SILICA-BASED COLUMNS
}

\author{
Md. Mahamud Hasan, Tania Hossain, Ashish Kumar Majumder, Pilu Momtaz, \\ Tarana Sharmin, Abu Sufian and Sharif AKhteruzzaman ${ }^{1 *}$ \\ National Forensic DNA Profiling Laboratory, Dhaka Medical College Campus, \\ Dhaka-1000, Bangladesh
}

Key words: Forensic, Bone, Tooth, Skeleton, Demineralization, Genomic DNA extraction

\begin{abstract}
A highly efficient strategy for recovery of genomic DNA from bone and tooth samples is presented by complete demineralization of the bone pieces or intact tooth with high concentration of EDTA followed by spin column treatment without the need of mechanical grinding or cryogenic method for pulverizing the samples. The DNA yield was between 8 and $12 \mathrm{ng} / \mu \mathrm{l}$ from approximately $1-2 \mathrm{~g}$ of the starting material. Completed DNA profiles were obtained from of all the bones (52) and tooth (270) samples received from the unidentified victims from a recent building collapse, the Rana Plaza disaster in Dhaka, Bangladesh.
\end{abstract}

\section{Introduction}

In a mass disaster or forensic identification, where dead body or its remains are highly decomposed or severely burnt, bone and tooth are often the only accessible source of DNA. Due to their unique composition and structure, DNA molecules in bone and teeth are largely protected from environmental challenges and/or biological attack. For almost three decades short tandem repeat (STR) based DNA typing have been successfully used for human identification in mass fatality incidents ${ }^{(1-3)}$. Forensic laboratories have developed a variety of procedures for DNA extraction from diverse types of human tissues(4). However, efficient protocol for obtaining DNA from bone or tooth samples has yet to achieve the kind of robustness attained with regard to blood or tissue samples. So, new methods are constantly being developed, which is beyond the scope of this article to summarize ${ }^{(5-9)}$.

Bone is a connective tissue largely composed of collagen and inorganic mineral called hydroxyapatite ${ }^{(10)}$. DNA has a strong affinity for hydroxyapaptite and its degradation is linked to the extent of crystalinity loss in hydroxyapatite as well as the loss of collagen ${ }^{(11)}$. Bone density is another intrinsic factor in survival of bone material. There is significant difference in the bone density between men and women, and in

*Author for correspondence: <sharif_akhteruzzaman@yahoo.com>. ${ }^{1}$ Department of Biochemistry and Molecular Biology, University of Dhaka, Dhaka-1000, Bangladesh. 
different areas of the skeletal element morphology ${ }^{(12)}$. A tooth on the other hand is composed of three major tissues; enamel, dentin and pulp. Enamel is the hardest tissue in human body being $96 \%$ mineral and contains no DNA ${ }^{(13)}$. Dentins usually do not contain any nucleated cell bodies, other than some mitochondrial DNAs that accumulate from the odontoblastic process ${ }^{(14)}$. Dental pulp is a highly vascularized connective tissue containing numerous cell types and rich in DNA. Since dentin and pulp is covered with enamel, this tissue provides a physical barrier protecting DNA within the tooth from external condition like heat, sunlight, moisture and microbial attack ${ }^{(15)}$.

Most of the genomic DNA isolation methods use organic solvents involving phenol/chloroform, or silica-binding extraction from powdered bone or tooth materials. Mechanical grinding of whole tooth or bone requires a separate pre-amplification laboratory area and increase the risk of contamination from the dust particles. Although organic method perform well, it uses hazardous chemicals and sometimes fail to remove PCR inhibitors. Inhibition is often less problem with silica based method because of its high specificity of DNA binding. In this study, a highly efficient DNA extraction method is reported from not-buried bone or tooth samples using a combination of complete demineralization and silica based for STR typing without the need of mechanical grinding and use of toxic chemicals.

\section{Materials and Methods}

A total of 270 tooth and 52 bone samples were collected from the body remains of Rana Plaza building collapse victims (April 24, 2013). The samples were collected between 7 and 15 days after the disaster and before the burial process.

The surface of the bone and tooth samples such as, the adherent tissues and dirt were cleaned by washing with deionized water followed by $95 \%$ ethanol with the help of sterile cotton wool. The samples were then air dried overnight at room temperature under sterilized fume hood. The collected tooth samples were left intact and the bone samples were cut into small pieces $(\sim 0.5 \mathrm{sq} \mathrm{cm})$ by autopsy saw. Every sample was prepared separately using sterile, disposable tools in an isolated area.

About $1-2 \mathrm{~g}$ of bone pieces or whole tooth weighing approximately $2.0 \mathrm{~g}$ was incubated in $10 \mathrm{ml}$ EDTA solution $(0.5 \mathrm{M}, \mathrm{pH} 7.5)$ in a $50 \mathrm{ml}$ falcon tube and placed on a rotary shaker at room temperature. EDTA solution was replaced every 24 hours until the calcium was removed completely. Complete decalcification from approximately $1-2 \mathrm{~g}$ of bone or a single molar tooth takes about 12 - 15 days depending on the amount of calcium present in the sample.

After decalcification the samples loses their hardness and become very soft. The decalcified bone and tooth samples were then incubated overnight in $700 \mu$ l extraction buffer containing $10 \mathrm{mM}$ tris- $\mathrm{HCl}, \mathrm{pH} 8.0,2 \%$ SDS, $10 \mathrm{mM} \mathrm{NaCl}, 10 \mathrm{mM}$ EDTA and

proteinase $\mathrm{K}(20 \mathrm{mg} / \mathrm{ml})$ on a rotary shaker at $56^{\circ} \mathrm{C}$. Next day, $500 \mu \mathrm{l}$ of the dissolved 
bone or tooth sample was transferred into a $1.5 \mathrm{ml}$ micro centrifuge tube. Two hundred $\mu \mathrm{l}$ of proprietary GBT buffer (Geneaid, Taiwan) was added into the tube, mixed by vigorous shaking and incubated for $20 \mathrm{~min}$ at room temperature. The sample lysate was then vortexed for $10 \mathrm{sec}$ after the addition of $700 \mu \mathrm{l}$ absolute alcohol. The whole sample mixture was transferred on to a GD column (Geneaid, Taiwan) in two steps (600 $\mu \mathrm{l}$ each), centrifuged at 13,000 rpm for $1 \mathrm{~min}$ and the filtrate was discarded. Then, $400 \mu \mathrm{l}$ of W1 buffer (Geneaid, Taiwan) was added to the GD column, placed in a $2.0 \mathrm{ml}$ collection tube and centrifuged at 13,000 rpm for $1 \mathrm{~min}$. The content of the collection tube was discarded. The process was repeated with a proprietary ethanol added wash buffer (Geneaid, Taiwan). Finally, the DNA was eluted in a fresh $2.0 \mathrm{ml}$ collection tube after adding $30 \mu \mathrm{L}$ $\mathrm{ddH}_{2} \mathrm{O}$ (preheated at $70^{\circ} \mathrm{C}$ ) to the centre of the dried column matrix, and centrifugation at 13,000 rpm for $1 \mathrm{~min}$.

The amount of DNA isolated from each sample was quantified by NanoDrop ${ }^{\mathrm{TM}} 100$ (Thermo Scientific, USA) spectrophotometer. The average DNA yield was between 8 and $10 \mathrm{ng} / \mu \mathrm{l}$ from approximately $1-2 \mathrm{~g}$ of bone or one whole tooth. In order to check the extent of DNA degradation and presence of PCR inhibitors about $10 \%$ of the extracted DNA samples were subjected to real time PCR on ABI 7500 (Applied Biosytems, USA) using Quantifiler ${ }^{\circledR}$ Duo DNA quantification kit following manufacturers protocol. Internal positive and negative control served as measure of quality control.

For autosomal STR typing, all the samples were PCR amplified by using Identifiler ${ }^{\mathrm{TM}}$ (Applied Biosystems) PCR amplification kit. Approximately 1 - 2 ng of genomic DNA was amplified in a Veriti ${ }^{\circledR}$ thermal cycler. Both $\mathrm{X}$ and $\mathrm{Y}$ chromosome STR typing were also performed depending on the relationship of the reference sample donor with the victim by using Argus X (Qiagen, Germany), and Y filer (Applied Biosystems) PCR amplification kit. For all the multiplexes the PCR amplification was carried out according to the protocol provided by the manufacturer, except for the number of PCR cycles, which were increased to 35 cycles. PCR amplified products were separated by capillary electrophoresis on ABI Prism 3500 Genetic Analyzer (Applied Biosystems, USA) using POP-4 polymer and data collection software ver. 2.0. Peak sizing and genotyping assignments were done by GeneMapper ID- $\mathrm{X}^{\mathrm{TM}}$ v1.2. Alleles were designated according to the International Society for Forensic Genetics (ISFG) guidelines for forensic STR analysis.

\section{Results and Discussion}

The sample type categories collected from the dead body/body remains of the Rana Plaza disaster victims is presented in Fig. 1. The present study presents a robust and reliable DNA extraction method from bone and tooth samples by total demineralization with high concentration of EDTA. The demineralized samples were subjected to proteinase K digestion and silica based spin columns where chaotropic salts were used to mediate highly specific binding of DNA to silica particles via ionic salt bridges. A total 
of 322 samples, which include 52 bones and 270 tooth, were subjected to DNA extraction by this modified method. The DNA yield was between 8 and $10 \mathrm{ng} / \mu \mathrm{L}$ from about $1-2 \mathrm{~g}$ of starting material of bone or whole tooth. About 1 - 2 ng of DNA was subsequently PCR amplified using Identifiler ${ }^{\mathrm{TM}}$ PCR amplification kit. Identifiler ${ }^{\mathrm{TM}}$ is a widely used human identification kit that amplifies 15 autosomal short tandem repeats (STR) loci such as, D8S1179, D21S11, D7S820, CSF1PO, D3S1358, TH01, D13S317, D16S539, D2S1338, D19S433, VWA, TPOX, D18S51, D5S818, FGA plus the sex typing marker amelogenin, in a single reaction. PCR products were separated on an applied biosystems 3500 Genetic Analyzer and the DNA profiles were generated by analyzing the data with GeneMapper ID-X software. Among the samples analyzed, complete DNA profile was obtained from 204, partial DNA profiles (more than 10 loci out of 15) from 108 and no profile from 10 (Fig. 2) in the first stage. It was not surprising that the success of getting good quality DNA from bone or tooth samples was often compromised due to the presence of PCR inhibitors like humic acid, tannins, iron, cobalt and other materials that could be acquired as the samples were exposed to soil and rubbles. Therefore, PCR condition was modified by increasing the PCR cycle from the recommended 28 to 32 cycles and diluting the template DNA which also dilutes the PCR inhibitor present, if

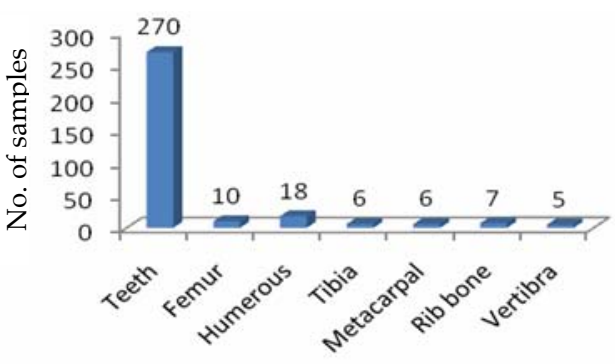

Type of samples

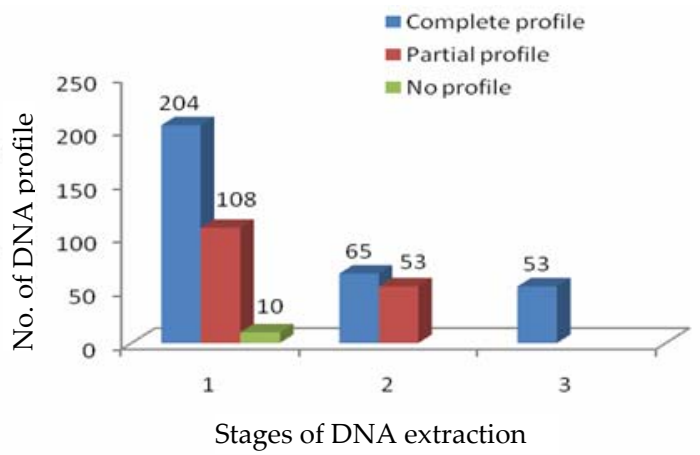

Fig. 2. Success rate of obtaining DNA profiles at different stages of DNA extraction.

Fig. 1. Sample type category subjected to DNA extraction.

any. In the next stage, 128 samples with partial or no profiles were re-amplified with this modified PCR protocol. This modification further improved the situation and complete DNA profile was obtained from 65 samples and partial profile from 53. Since the DNA recovery from bone and tooth samples also depends on the skeletal elements morphology and bone density as well as on tooth selection, rest of the 53 samples with partial DNA profile were subjected for re-extraction of the DNA. After re-extraction, PCR was repeated with the modified protocol and the effort was successful in obtaining the complete DNA profile for all the samples. Fig. 3a shows partial DNA profile obtained in the first un-modified PCR. The completed DNA profile obtained after the modification is shown in Fig. 3b. It is worth to mention here that, complete genotype was obtained from 


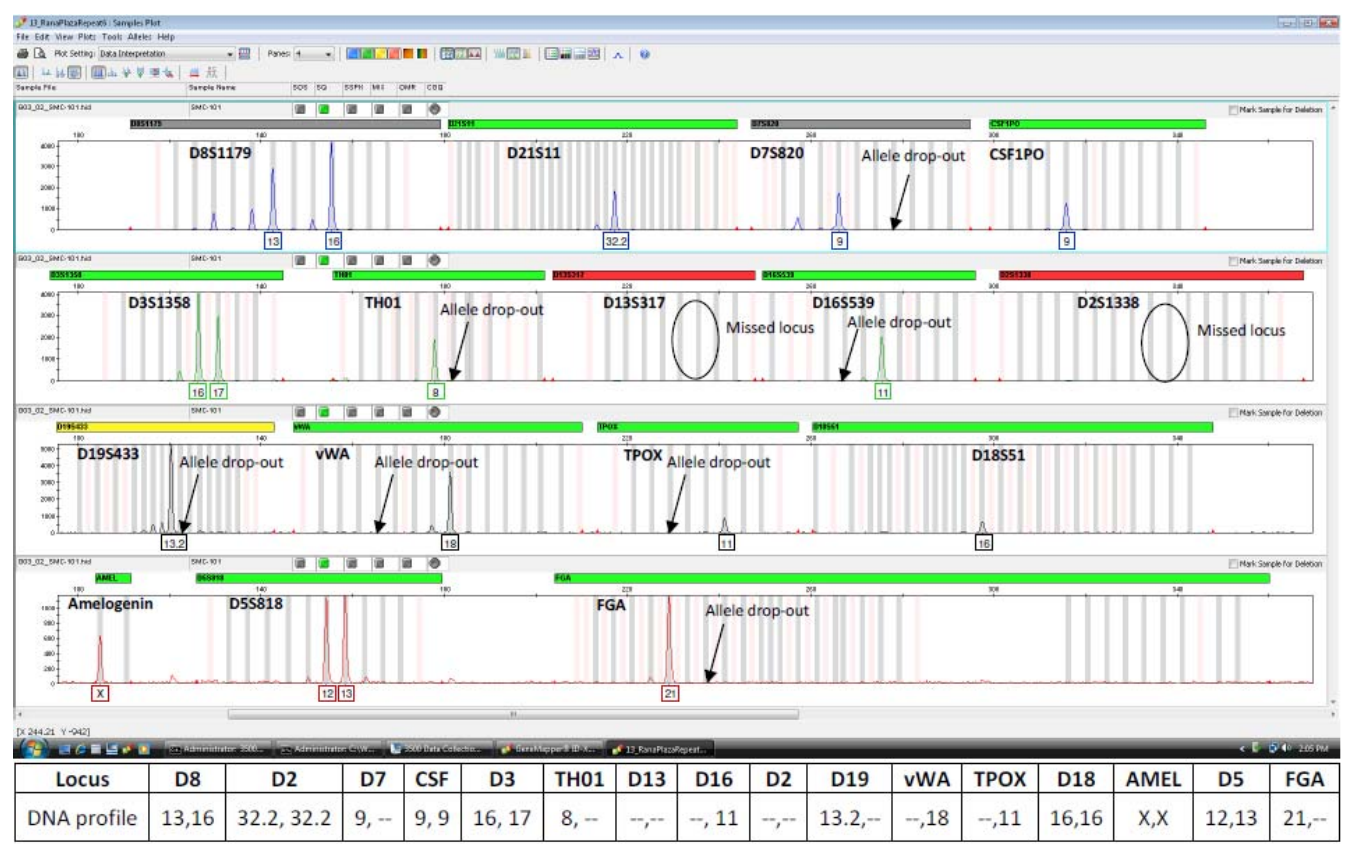

Fig. 3a. Partial DNA profile obtained from a bone sample showing missed locus at D13S317 and D2S1338. Other five loci such as, D7S820, TH01, D16S539, D19S433, vWA, TPOX and FGA show one allele drop-out.

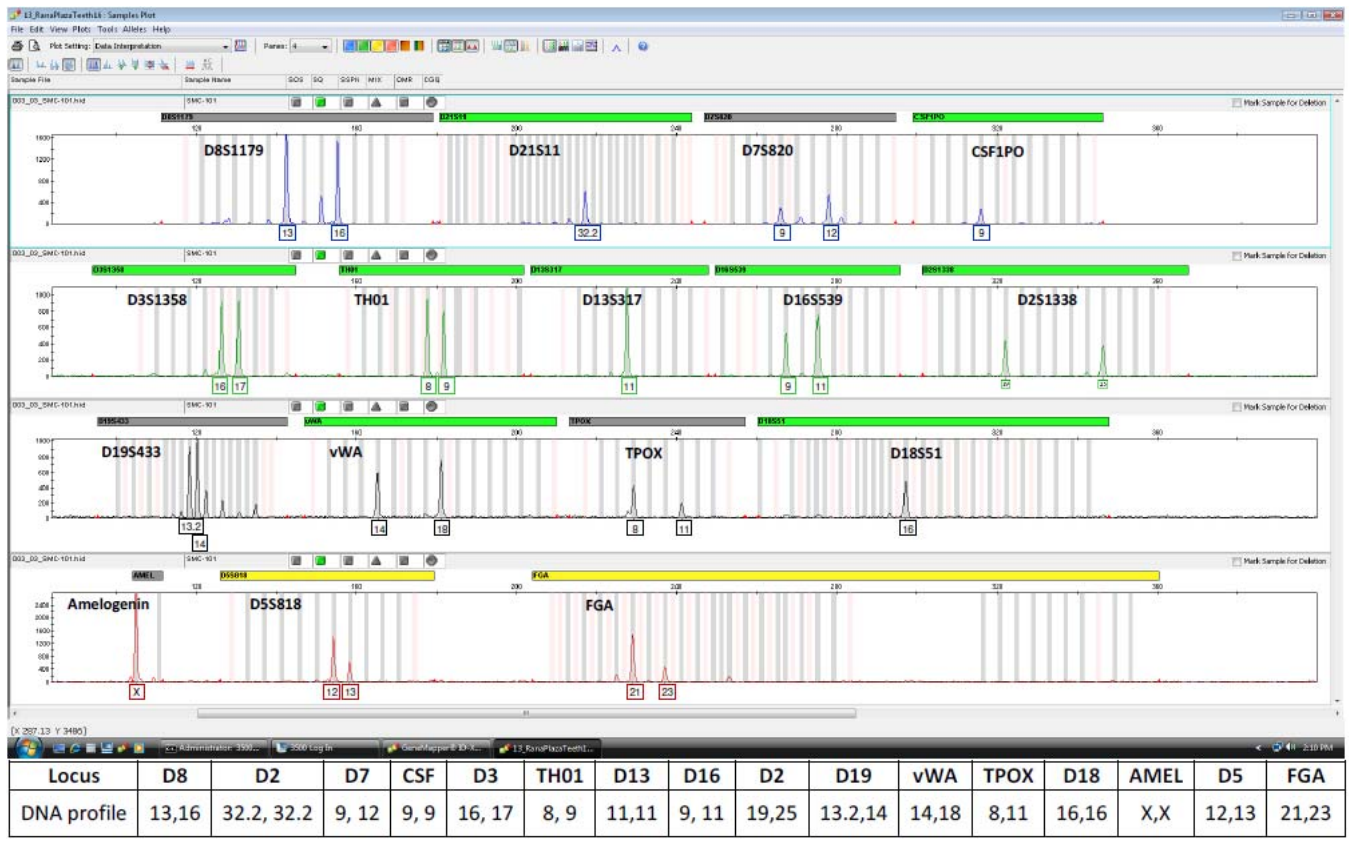

Fig. 3b. Complete DNA profile obtained from the same sample (Fig. 3a) after modifying the PCR conditions. 
D13S317 $(11,11)$ and D2S1338 $(19,25)$ loci which were missed in the unmodified extraction and all the sister alleles dropped in the earlier extraction were clearly identified.

In a mass disaster, recovery of STR data from bones and tooth exposed to environmental conditions has become a valuable tool for the identification of missing individuals(16). In case of extreme degradation bone and tooth may be the only suitable material available for successful DNA typing. However, relatively specialized techniques are required for the extraction of DNA from these samples. The physical barrier in bone and tooth samples due to the presence of high levels of calcium also hinders the access of reagents in the extraction process. The co-extraction of compounds inhibitory to PCR process is also another major problem for samples exposed to soil or other environmental contaminants ${ }^{(17) .}$

This study, has demonstrated a high efficiency DNA extraction method from bone and tooth samples with complete demineralization without mechanical grinding or cryogenic pulverization of the samples. Furthermore, this method was proven extremely effective in retrieving STR profiles from small quantities of starting material for challenging specimens previously compromise in forensic DNA typing.

\section{References}

1. Thompson R, S Zoppis and B McCord 2012. An overview of DNA typing methods for human identification: Past, present and future. Methods Mol. Biol. 830: 3-16.

2. Whitaker JP, TM Clayton, AJ Urquhart, ES Millican, TJ Downes, CP Kimpton, et al. 1995. Short tandem repeat typing of bodies from a mass disaster: high success rate and characteristic amplification pattern of highly degraded samples. Biotechniques. 18: 670-677.

3. Budimlija ZM, MK Prinz, A Zelson-Mundorf, J Wiersema, E Bartelink, G MacKinnon, et al. 2003. World Trade Center human identification project: Experience with individual body identification case. Croat. Med. J. 44: 259-63.

4. McDonald J and C Lehman 2012. Forensic DNA analysis. Clin. Lab. Sci. 25: 109-113.

5. Piglionica M, A De Donnos, SL Baldassarra, V Santoro, A Scorca, F Introna, et al. 2012. Extraction of DNA from bones in case where expectation of success are low. Amer. J. Forensic Med. Pathol. 33: 322-327.

6. Handt O, M Moss, M Krings and S Paabo 1994. Ancient DNA: methodological challenges. Experimentia 50: 524-529.

7. Amory S, R Huel, A Bilic, O Loreille, TJ Parsons 2012. Automatable full demineralization DNA extraction procedure from degraded skeletal remains. Forensic Sci. Int. Genet. 6: 398-406.

8. Alonso A, S Andelinović, P Martín, D Sutlović, I Erceg, E Huffine, LF de Simón, et al. 2001. DNA typing from skeletal remains: Evaluation of multiplex and megaplex STR systems on DNA isolated from bone and teeth samples. Croat. Med. J. 42: 260-266.

9. Odile ML, MD Toni, AI Jodi, DC Michael, JP Thomas 2007. High efficiency DNA extraction from bone by total demineralization. Forensic Sci. Int. Genet. 7: 191-195.

10. MJ, CM Nelson-Marsh, J Hiller, CI Smith, JP Roberts, RV Prigodich et al. 202. The survival of organic matter in bone: A review. Archeometry 44: 383-394. 
11. Gotherstrom A, MJ Collins, A Angerbjorn and K Liden 2002. Bone preservation and DNA amplification. Archeometry 44: 395-404.

12. Galloway A, P Willey and L Snyder 1996. Human bone mineral densities and survival of bone elements: A contemporary sample, In: Haglund WD, Sorg MH (Eds), Forensic taphonomy: the postmortem fate of human remains, Boca Raton (FL): CRC Press, p. 296317.

13. Nanci A. 2003. Enamel: Composition, formation and structure, sixth ed. Mosby, St Louis, Missouri, USA.

14. Vertucci FJ and RL Anthony 1986. A scanning electron microscopic investigation of accessory foramina in the furcation and pulp chamber floor of molar teeth, Oral Surgery, Oral Medicine, and Oral Pathology 62: 319-326.

15. Rohland N and M. Hofreiter 2007. Ancient DNA extraction from bones and teeth, Nature. Protocols 2: 1756-1762.

16. Hochmeister MN, B. Budowle, UV Eggmann, CT Comey and R. Dirnhofer. 1991. Typing of deoxyribonucleic acid (DNA) extracted from compact bone from human remains. J. Forensic Sci. 36: 1649-1661.

17. Holland MM, CA Cave, CA Holland and TW Bill 2003. Development of a quality, high throughput DNA analysis procedures for skeletal sample to assist with the identification of victims from the World Trade Center attack. Croat. Med. J. 44: 264-72.

(Manuscript received on 1 April, 2014; revised on 6 July, 2014) 